\begin{tabular}{|c|c|c|c|}
\hline & $\begin{array}{l}\text { Escola Superior } \\
\text { de Cestáoe } \\
\text { Tecnologia } \\
\text { [PSantarém }\end{array}$ & 埋 & $\begin{array}{l}\text { ISSN 2029-7564 (online) } \\
\text { SOCIALINES TECHNOLOGIJOS } \\
\text { SOCIAL TECHNOLOGIES } \\
2014,4(1) \text {, p. } 168-178\end{array}$ \\
\hline
\end{tabular}

\title{
POWER THROUGH THINGS: FOLLOWING TRACES OF COLLECTIVE INTELLIGENCE IN INTERNET OF THINGS
}

\author{
Monika Mačiulienè \\ Mykolas Romeris University, Lithuania, maciuliene@mruni.eu \\ doi:10.13165/ST-14-4-1-11
}

\section{Abstract}

Purpose - it is becoming increasingly difficult to ignore the input Internet of Things (IoT) has to offer in the development of public, business and other societal structures. Therefore, this paper seeks to determine the current state of knowledge in the field of IoT in terms of wisdom creation and emergence of collective intelligence. First, we discuss the concept of collective intelligence and then define the phenomena of IoT and identify the areas of its application. Later, the author reviews how intelligent outputs of IoT are defined in the scientific literature. These findings of theoretical investigation may shed some light on the research field that is promising but still very vague.

Design/methodology/approach - this article provides a general overview of IoT concept and its growing relation to collective intelligence. Methods of document analysis and content analysis were applied. Theoretical analysis enabled recognition of IoT phenomena in relation to wisdom creation and emergence of collective intelligence.

Findings - general overview of the field revealed that new understanding of collective intelligence surfaces. Often intelligent behaviour and decisions emerge from ever-increasing cooperation between 'things' and humans. The variety of new concepts and authors trying to describe relationship of 'things' with each other and humans when creating intelligent outcomes revealed that this field is still in its very infancy and needs considerable amount of industry and scientific efforts to be understood and executed.

Research limitations - although the paper has successfully demonstrated that IoT provides vast amounts of data for people to process and create knowledge, this could be 
considered only as an initial phase in studying the field. IoT and its intelligent outcomes need more investigation in terms of real life case studies and industry reviews in order to create valid definitions, models and future guidelines.

Practical implications - this study provides an exciting opportunity to advance our knowledge on Internet of Things and could be used as theoretical background for further analysis of emergence of collective intelligence in interactive networks of people and things.

Value - to date there has been little research summarising scientific efforts in the field of IoT. This paper provides a general overview of the knowledge on IoT and could be used as guidelines for further research.

Keywords: Internet of Things, Collective Intelligence, Wisdom.

Research type: General overview.

\section{Introduction}

Internet of things (IoT) stands in the heart of revolution that is taking place right now while innovative organisations are finding novel ways of merging physical and digital worlds. Physical objects in our environment are becoming more interactive, IP-enabled and smart (Rose, McClean, \& Lisserman, 2012) The research in this area is supported by the collaborative efforts from academia, industry, and standardisation bodies in several communities such as telecommunication, semantic Web, and informatics (Barnaghi \& Wang, 2012). As analysts at McKinsey \& Company have pointed out, "when objects can both sense the environment and communicate, they become tools for understanding complexity and responding to it swiftly" (Chui, Loffler, \& Roberts, 2010). However, most of the works focused on defining IoT and process management, potential usage of generated data has been left out of the scope.

Collective intelligence was discussed in various settings. For example, groups of animals and people working together for greater cause with greater outcomes than individually (Bonabeau, Dorigo, \& Theraulaz, 1999; Camazine et al., 2001; Khalique, Md Isa, \& Nassir bin Shaari, 2013; Malone, Laubacher, \& Dellarocas, 2010; Nguyen, 2008; Salminen, 2012; Wise, Paton, \& Gegenhuber, 2012). This article takes it even further and discusses collective intelligence in the light of Internet of Things and how that could bring more intelligent solutions in business situations and societal problems. This article aims at reviewing the possible input IoT could offer in the emergence of collective intelligence. In this paper, we provide an overview of different aspects of Internet of Things, how it could benefit emergence of collective intelligence, including the analysis of challenges that must be overcome, as well as cases of IoT application that might help make more informed and intelligent decisions. This paper introduces a discussion on relation between concepts of Internet of Things and collective intelligence and how this relationship fits into the concept of a future society. 


\section{Creation of Wisdom and Collective Intelligence}

A large and growing body of literature has investigated the notion of collective intelligence (Luo, Xia, Yoshida, \& Wang, 2009; Malone et al., 2010; Nguyen, 2008; Woolley, Chabris, Pentland, Hashmi, \& Malone, 2010). These studies closely relate to the swarm intelligence research analysing intellect emerging in a group of interrelated simple agents working together. The essence of this concept can be best illustrated with processes of self-regulation, foraging, cooperative transportation and nesting of social insect groups, such as wasps, bees and ants. Numerous scholars have argued that sporadic agents cannot solve complex problems on their own but cooperation can help to achieve the goals that benefit the whole community (Bonabeau et al., 1999; Camazine et al., 2001; Dorigo \& Stützle, 2004; Krause, Ruxton, \& Krause, 2010). Communication of human groups has a lot in common with swarm intelligence - a group of people has more abilities and resources to process large amounts of information and make decisions based on the acquired knowledge. Increasingly, intelligence is seen not as having its locus in the individual, but in the network of relationships that the individual has with the external world and other individuals.

The concept of collective intelligence experienced a recent shift of paradigm driven by changes "of the Internet from vision of network of networks of computers to a global platform of people, computers, networks, and devices offering services and enabling interaction" (Xhafa \& Bessis, 2014). Information is now collected using many interconnected platforms and devices. This change generates massive amounts of data in the context of our habitat, which could be stored in clouds and processed to get the knowledge required to make more intelligent decisions. Importance of the amount of data generated can be best described by the process of humans processing data illustrated in Picture 1 "Humans turn data into knowledge" below.

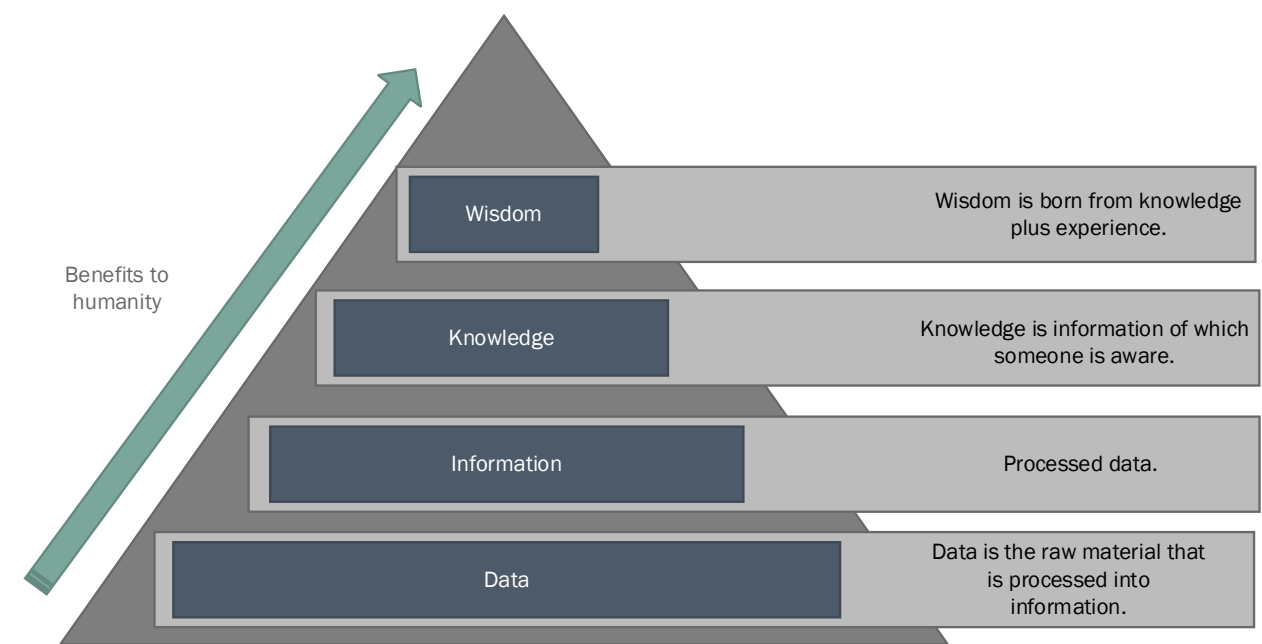

Source: adapted from Evans (2011)

Picture 1. Humans turn data into knowledge 
As pointed out by researchers at Cisco, the more raw data we have the more wisdom we can generate, which the humanity can benefit from (Evans, 2011). Next section of the article explores the concept of Internet of Things and its current and potential role in data generation.

\section{Current State of Knowledge: Internet of Things}

The concept of Internet of Things was first used in 1999, when assistant brand manager Kevin Ashton at Procter \& Gamble came up with an idea to integrate RFID chips into products in order to optimise and improve efficiency of the supply chain. In his recent publication Ashton (2009) proposes that having humans input the data is highly inefficient and it is much more rational to get information from the objects themselves. As computer parts are becoming cheaper and smaller it is possible to incorporate them in a variety of everyday objects. Digitalisation of physical world is confirmed by business and industry analysts. Ericsson, McKinsey \& Company, Libelium estimate that 50 billion physical objects will be connected to the Internet by 2020 (Chui et al., 2010; Ericsson, 2013; Libelium, 2014). These numbers are confirmed by major players in the market, such as Cisco and General Electric which predict that IoT will have an economic impact of over $\$ 14$ trillion by 2020 (Bradley, Barbier, \& Handler, 2013; Evans \& Annunziata, 2012). Companies in sectors ranging from health care to the logistics are already spending billions to create new and innovative businesses featuring usage of IoT. Due to a wide range of application areas comprehensive investment trends into IoT processes and building of infrastructure are hard to come by but CB Insights estimate venture capital investment of over $\$ 750$ million in more than 100 IoT companies during 2012 (CB Insights, 2013).

Even though the name suggests that IoT is merely an extension of internet development, it is becoming obvious that IoT is a separate system or group of systems operating in its own infrastructure. There are many business and scientific efforts to define IoT and its building blocks. They are summarised in Table 1 "Definitions of Internet of Things" below.

Table 1. Definitions of Internet of Things

\begin{tabular}{|l|l|}
\hline \multicolumn{1}{|c|}{ Authors } & \multicolumn{1}{c|}{ Definitions } \\
\hline Chase (2013) & $\begin{array}{l}\text { "The IoT creates an intelligent, invisible network fabric that can be sensed, } \\
\text { controlled and programmed. IoT-enabled products employ embedded } \\
\text { technology that allows them to communicate, directly or indirectly, with } \\
\text { each other or the Internet." }\end{array}$ \\
\hline $\begin{array}{l}\text { Dlodlo et al. } \\
\text { (2012) }\end{array}$ & $\begin{array}{l}\text { "The Internet of Things is what happens when everyday ordinary objects } \\
\text { have inter-connected microchips inside them." }\end{array}$ \\
\hline $\begin{array}{l}\text { EU FP7 Project } \\
\text { CASAGRAS } \\
\text { (2009) }\end{array}$ & $\begin{array}{l}\text { "A global network infrastructure, linking physical and virtual objects } \\
\text { through the exploitation of data capture and communication capabilities. } \\
\text { This infrastructure includes existing and evolving Internet and network } \\
\text { developments. It will offer specific object-identification, sensor and connec- }\end{array}$ \\
\hline
\end{tabular}




\begin{tabular}{|c|c|}
\hline & $\begin{array}{l}\text { tion capability as the basis for development of independent federated services } \\
\text { and applications. These will be characterized by a high degree of autonomous } \\
\text { data capture, event transfer, network connectivity and interoperability." }\end{array}$ \\
\hline $\begin{array}{l}\text { European } \\
\text { Commission \& } \\
\text { CABAS (2008) }\end{array}$ & $\begin{array}{l}\text { "Things having identities and virtual personalities, operating in smart spaces } \\
\text { using intelligent interfaces to connect and communicate within social, } \\
\text { environmental and user contexts." }\end{array}$ \\
\hline $\begin{array}{l}\text { Gubbi et al. } \\
(2013)\end{array}$ & $\begin{array}{l}\text { "Interconnection of sensing and actuating devices providing the ability to } \\
\text { share information across platforms through a unified framework, developing } \\
\text { a common operating picture for enabling innovative applications. This is } \\
\text { achieved by seamless large-scale sensing, data analytics and information } \\
\text { representation using cutting edge ubiquitous sensing and cloud computing." }\end{array}$ \\
\hline $\begin{array}{l}\text { Internet of } \\
\text { Things } \\
\text { European } \\
\text { Research } \\
\text { Cluster (2012) }\end{array}$ & $\begin{array}{l}\text { "Things' are active participants in business, information and societal } \\
\text { processes where they are enabled to interact and communicate among } \\
\text { themselves and with the environment by exchanging data and information } \\
\text { sensed about the environment, while reacting autonomously to real/physical } \\
\text { world events and influencing it by running actions and create services with } \\
\text { or without direct human intervention." }\end{array}$ \\
\hline $\begin{array}{l}\text { Middleton et } \\
\text { al. (2013) }\end{array}$ & $\begin{array}{l}\text { "The Internet of Things is the network of physical objects that contain } \\
\text { embedded technology to communicate and sense or interact with their } \\
\text { internal states or external environment." }\end{array}$ \\
\hline $\begin{array}{l}\text { Tarkoma \& } \\
\text { Katasonov } \\
(2011)\end{array}$ & $\begin{array}{l}\text { "A global network and service infrastructure of variable density and } \\
\text { connectivity with self-configuring capabilities based on standard and } \\
\text { interoperable protocols and formats. IoT consists of heterogeneous things } \\
\text { that have identities, physical and virtual attributes, and are seamlessly and } \\
\text { securely integrated into the Internet." }\end{array}$ \\
\hline
\end{tabular}

Source: developed by the author (2014)

Table 1 shows us that it is becoming increasingly difficult to ignore the input IoT has to offer in the development of public, business and other societal structures. Unfortunately, as pointed out by (Dlodlo et al., 2012) "the picture is not clear on who is doing what where and, thus making it difficult not only for newcomers into this field to define their space and also engage with potential collaboration partners, but also for the relatively established researchers as well to gain the necessary support in their work".

IoT covers various types of relationships (things to person, person to thing, thing to thing) offering new ways of operating in day-to-day life and solving problems. Literature analysis of the potential and existing application areas has revealed that there is no clear consensus on where IoT is and can be used. While some authors (Chui et al., 2010) focus on the functions of IoT, such as tracking behaviour, enhanced situational awareness, sensor-driven analytics, process optimisation, optimised resource consumption and complex autonomous systems, others (Atzori, Iera, \& Morabito, 2010; Dlodlo et al., 2012; Libelium, 2014; Mahidhar \& Schatsky, 2013; Presser \& Krco, 2011; Tarkoma \& Katasonov, 2011) provide lists of industries where IoT is being used. Efforts of researchers in latter group are summarised in Table 2 "Application areas of IoT by industries" below. 
Table 2. Application areas of IoT by industries

\begin{tabular}{|c|c|c|c|c|c|c|}
\hline & $\begin{array}{c}\text { Tar- } \\
\text { koma \& } \\
\text { Kata- } \\
\text { sonov } \\
(2011)\end{array}$ & $\begin{array}{l}\text { Presser } \\
\& \text { Krco } \\
(2011)\end{array}$ & $\begin{array}{l}\text { Atzori } \\
\text { et al. } \\
(2010)\end{array}$ & $\begin{array}{l}\text { Libe- } \\
\text { lium } \\
(2014)\end{array}$ & $\begin{array}{l}\text { Dlodlo } \\
\text { et al. } \\
(2012)\end{array}$ & $\begin{array}{l}\text { Mahid- } \\
\text { har \& } \\
\text { Schatsky } \\
(2013)\end{array}$ \\
\hline Energy & $\mathrm{x}$ & $\mathrm{x}$ & & & $\mathrm{x}$ & \\
\hline $\begin{array}{l}\text { Medical technology \& } \\
\text { health }\end{array}$ & $\mathrm{x}$ & $\mathrm{x}$ & $\mathrm{x}$ & $\mathrm{x}$ & $\mathrm{x}$ & $\mathrm{x}$ \\
\hline Buildings & $\mathrm{x}$ & $\mathrm{x}$ & $\mathrm{x}$ & $\mathrm{x}$ & $\mathrm{x}$ & $\mathrm{x}$ \\
\hline Transportation & $\mathrm{x}$ & $\mathrm{x}$ & $\mathrm{x}$ & & $\mathrm{x}$ & $\mathrm{x}$ \\
\hline Smart living & $\mathrm{x}$ & $\mathrm{x}$ & $\mathrm{x}$ & & & $\mathrm{x}$ \\
\hline Cities & $\mathrm{x}$ & $\mathrm{x}$ & & $\mathrm{x}$ & & $\mathrm{x}$ \\
\hline Retail & & $\mathrm{x}$ & & $\mathrm{x}$ & $\mathrm{x}$ & \\
\hline Agriculture & & $\mathrm{x}$ & & $\mathrm{x}$ & $\mathrm{x}$ & \\
\hline $\begin{array}{l}\text { Factory \& industrial } \\
\text { control }\end{array}$ & & $\mathrm{x}$ & $\mathrm{x}$ & $\mathrm{x}$ & $\mathrm{x}$ & $\mathrm{x}$ \\
\hline Supply chain \& logistics & & $\mathrm{x}$ & $\mathrm{x}$ & $\mathrm{x}$ & $\mathrm{x}$ & \\
\hline Emergency \& security & & $\mathrm{x}$ & & $\mathrm{x}$ & & \\
\hline User interaction & & $\mathrm{x}$ & $\mathrm{x}$ & & & \\
\hline Culture \& tourism & & $\mathrm{x}$ & & & & \\
\hline Environment & & $\mathrm{x}$ & & $\mathrm{x}$ & $\mathrm{x}$ & \\
\hline Water & & & & $\mathrm{x}$ & & \\
\hline \multicolumn{7}{|l|}{ Metering } \\
\hline Animal farming & & & & $\mathrm{x}$ & & \\
\hline Insurance & & & & & $\mathrm{x}$ & \\
\hline Information security & & & & & $\mathrm{x}$ & \\
\hline Education & & & & & $\mathrm{x}$ & \\
\hline Telecommunication & & & & & $\mathrm{x}$ & \\
\hline
\end{tabular}

Source: Developed by the author (2014)

IoT is a multidisciplinary domain and cannot be attributed to a single market. Moreover, it is still developing and defining itself, so there is no definitive list of usage areas but Table 2 gives us a glimpse of how wide IoT usage can be. Some elements already exist successfully in various settings of our everyday life. IoT covers a large number of themes and industries, so the outputs or data that could be later useful for the collective intelligence to emerge are highly dependent on its application areas. Growing interconnectivity not only with each other but also with things allowed sharing of information and advanced achievements in society. 


\section{Outputs of IoT in Emergence of Collective Intelligence}

Wide scope of IoT application areas creates massive amounts of data (outputs). Previous sections revealed the importance of data in the knowledge formation process and recent shift in the paradigm of collective intelligence. Therefore, these outputs could be used to create situation awareness not only for the machines but also for humans. As pointed out by Barnaghi \& Wang (2012), "the understanding of a situation, or context, potentially enables services and applications to make intelligent decisions and to respond to the dynamics of their environments". Every new area comes with its own jargon. Hence, it is useful to review how outputs of IoT are defined by the scientists in the field, especially, when different authors see potential outputs in very different ways. Since most of these definitions differ in meaning and impact on emergence of collective intelligence, they will be discussed in more detail in Table 3 "Definitions of outputs created by IoT" below.

Table 3. Definitions of outputs created by IoT

\begin{tabular}{|c|c|c|}
\hline Term & Authors & Definition \\
\hline $\begin{array}{l}\text { Social Web } \\
\text { of Intelligent } \\
\text { Things }\end{array}$ & $\begin{array}{l}\text { Console et al. } \\
\text { (2011) }\end{array}$ & $\begin{array}{l}\text { Things are entities capable of an intelligent and social } \\
\text { behaviour. They can maintain and socialise knowledge and } \\
\text { can interact and communicate with people. }\end{array}$ \\
\hline $\begin{array}{l}\text { Embedded } \\
\text { Intelligence }\end{array}$ & $\begin{array}{l}\text { Guo et al. } \\
\text { (2011) }\end{array}$ & $\begin{array}{l}\text { Aims at revealing the individual behaviours, spatial contexts, } \\
\text { as well as social patterns and urban dynamics by mining the } \\
\text { digital traces left by people while interacting with IoT. It } \\
\text { explores interactions between people and things in order to } \\
\text { extract "embedded" intelligence about individual, environment } \\
\text { and society, which could enhance existing IoT systems. }\end{array}$ \\
\hline $\begin{array}{l}\text { Inter- } \\
\text { Cooperative } \\
\text { Collective } \\
\text { Intelligence }\end{array}$ & $\begin{array}{l}\text { Xhafa \& } \\
\text { Bessis (2014) }\end{array}$ & $\begin{array}{l}\text { ICCI is emerging as new multi domain feature where } \\
\text { knowledge could be created collectively. Parties creating } \\
\text { knowledge: internet users, intelligent networks of smart } \\
\text { things/devices, networks of producers and consumers or } \\
\text { any combination of them. In this way, knowledge can be } \\
\text { extracted and delivered on global scale. }\end{array}$ \\
\hline $\begin{array}{l}\text { Internet of } \\
\text { Intelligent } \\
\text { Things }\end{array}$ & $\begin{array}{l}\text { Xhafa \& } \\
\text { Bessis (2014), } \\
\text { Arsénio et al. } \\
\text { (2014) }\end{array}$ & $\begin{array}{l}\text { Growing amounts of interconnected mobile and wireless } \\
\text { devices allows IoT to expand to different application areas. } \\
\text { These devices increasingly can actuate on real world instead } \\
\text { of just observe it. Devices become therefore capable of acting } \\
\text { autonomously, demonstrating some degree of artificial } \\
\text { intelligence. Because of that, sharing of knowledge and ideas } \\
\text { between massive amounts of 'things' and people can provide } \\
\text { more accurate answers to complex problems than single } \\
\text { individuals. These new capabilities enable the development } \\
\text { of collective intelligence applications, because IoT goes } \\
\text { further than IoT paradigm of connecting billions of things, } \\
\text { into the paradigm of transforming everyday objects into } \\
\text { intelligent things that communicate with each other, and } \\
\text { with people (Arsénio et al., 2014) }\end{array}$ \\
\hline
\end{tabular}




\begin{tabular}{|c|c|c|}
\hline $\begin{array}{l}\text { Social } \\
\text { Internet of } \\
\text { Things }\end{array}$ & $\begin{array}{l}\text { Atzoria et } \\
\text { al. (2012), } \\
\text { Arsénio et al. } \\
(2014)\end{array}$ & $\begin{array}{l}\text { Yet another social approach to the Internet of Things. IoT } \\
\text { is all about integrating social networking concepts into } \\
\text { Internet of Things solutions. As a result, it has a potential } \\
\text { to support new applications and networking services in IoT } \\
\text { domain. 'Things' in this paradigm can publish themselves } \\
\text { and can be discovered through network }\end{array}$ \\
\hline
\end{tabular}

Source: developed by the author, 2014

Research on collective intelligence started out with the studies of small agents. Then, researchers focused on the interactions of human groups in the emergence of collective intelligence. Table 3 shows us that new understanding of collective intelligence is forming - meaning that knowledge is increasingly created together with 'things', mainly because IoT allows networks of smart objects and humans to exist. We are entering a new realm - where things have sensing abilities and are contextaware. According to Evans (2012), "add people and information into the mix and you get a network of networks where billions or even trillions of connections create unprecedented opportunities and give things that were silent a voice." IoT together with improved data collection/storage/sharing, innovations in the field of cloud computing and new tools for data analysis form an on-going big data revolution that drives a paradigmatic shift in the way businesses, organisations and governments work (Innocentive, 2012). Concepts of intelligent things communicating with each other and with humans discussed in Table 3 show that the field is new and emerging. Different scientists define same or similar concepts with different names. For example, 'things' with social attributes are named both "Social Web of Intelligent Things" and "Social Internet of Things", even though their meanings are similar. Paradigm of IoT is changing lives of societies and business whether its effects are obvious to the users or not (Arsénio et al., 2014). This simplistic research has thrown up many questions in the need of further investigation that will be discussed in the final section.

\section{Discussion and Recommendations for Further Research}

Initially, Internet of Things was supposed to be an ecosystem encompassing physical objects tagged with RFID sensors. However, it has flourished into a multidimensional network applied in diverse sectors of human life and able "to provide real-world intelligence and goal-oriented collaboration of distributed smart objects" (Gluhak et al., 2011). The understanding of a situation, or context, potentially enables us to create more value-added products and services in businesses and to solve complex societal problems by making more intelligent decisions. Overview of intelligent outputs IoT creates enhances our understanding on how it could benefit the formation of knowledge.

Emergence of collective intelligence with the assistance of new communication tools and forms would help navigating more effectively in the new environment using variety of diverse skills, experiences and abilities. This is critical in changing 
technological, economic and social environment (often referred to as 'new normal') we are currently living in. Researchers of collective intelligence believe that this form of intelligence could solve many problems not only in the business world but also in the society. If the debate is to be moved forward, a better understanding of a connection between collective intellect created by humans and machines needs to be developed. However, a number of important limitations need to be considered. First, flood of information benefits creation of knowledge, but in some cases, immense stream of data is not registered and recorded properly. Thus, the data is not understandable and accessible to those in need. Second, radical transformations mean that we will have to manage something that we have not created and this will pose unprecedented data privacy and security challenges.

The vision of interconnected objects working for the benefit of the society raises several important research questions. For example, how should public and business organisations be designed around vast amounts of information and new processes? How governance and control will change in new technological settings? How to obtain and select high quality data needed to make intelligent decisions? The insights of this research could be used in further studies to examine IoT adoption in wisdom creation and help business and government leaders in preparing for what is to come.

\section{References}

Arsénio, A., Serra, H., Francisco, R., \& Nabais, F. (2014). Inter-cooperative Collective Intelligence: Techniques and Applications. (F. Xhafa \& N. Bessis, Eds.) (Vol. 495, p. 1-37). Berlin, Heidelberg: Springer Berlin Heidelberg.

Ashton, K. (2009). That "Internet of Things" Thing. RFID Journal. Retrieved March 24, 2014, from http://www.rfidjournal.com/ articles/view?4986

Atzori, L., Iera, A., \& Morabito, G. (2010). The Internet of Things: A survey. Computer Networks, 54(15): 2787-2805.

Atzoria, L., Ierab, A., Morabitoc, G., \& Nittia, M. (2012). The Social Internet of Things (SIoT) - When social networks meet the Internet of Things: Concept, architecture and network characterization. Computer Networks, 56(16): 3594-3608.

Barnaghi, P., \& Wang, W. (2012). Semantics for the Internet of Things: Early Progress and Back to the Future. International Journal on Semantic Web \& Information Systems, 8(1),
1-21. Retrieved from http://www.igi-global. com/article/content/70584

Bonabeau, E., Dorigo, M., \& Theraulaz, G. (1999). Swarm Intelligence: From Natural to Artificial Systems. Oxford University Press. Bradley, J., Barbier, J., \& Handler, D. (2013). Embracing the Internet of Everything To Capture Your Share of \$ 14.4 Trillion (p. 1-18).

Camazine, S., Deneubourg, J.-L., Franks, N. R., Sneyd, J., Theraulaz, G., \& Bonabeau, E. (2001). Self-organization in Biological Systems (p. 560). Princeton University Press. CB Insights. (2013). The Internet of Things - \$752M Invested Across 113 Deals in the Last Year. [interactive]. [accessed 201403-25] <http://www.cbinsights.com/blog/ trends/internet-of-things-venture-capital $>$.

Chase, J. (2013). The Evolution of the Internet of Things (p. 1-7).

Chui, M., Loffler, M., \& Roberts, R. (2010). The Internet of Things (IoT). McKinsey Quartely, (2). Retrieved from http://www. ncbi.nlm.nih.gov/pubmed/24451454 
Console, L., Lombardi, I., Picardi, C., \& Simeoni, R. (2011). Toward a social web of intelligent things. AI Communications, 24, 265-279. doi:10.3233/AIC-2011-0503

Dlodlo, N., Foko, T., Mvelase, P., \& Mathaba, S. (2012). The State of Affairs in Internet of Things Research. Electronic Journal of Information Systems Evaluation, 15(3), 244259. Retrieved from http://search.ebscohost. com/login.aspx?direct=true\&profile $=$ ehost $\&$ scope $=$ site\&authtype $=$ crawler $\&$ jrnl $=156663$ 79\&AN=91546665\&h=ELZQ6IA7FKWX7n Unb3gJAvG\%2B2CmgAs5Wse1Q1kFdF616 I\%2FLKBfwgL\%2BZJ\%2FtoQYSlkLNdNM kHCgQJtp0mtL\%2F4MiA\%3D\%3D\&crl=c

Dorigo, M., \& Stützle, T. (2004). Ant colony optimization. MIT Press.

Ericsson. (2013). Annual Report 2013. Retrieved from http://www1.ericsson. com/thecompany/investors/financial_ reports/2013/annual13/sites/default/files/ download/pdf/EN_-_Ericsson_AR2013.pdf

EU FP7 Project CASAGRAS. (2009). CASAGRAS Final Report: RFID and the Inclusive Model for the Internet of Things (p. 88). Retrieved from http://www.grifs-project.eu/data/File/ CASAGRAS FinalReport (2).pdf

European Commission \& CABAS. (2008). Internet of Things in 2020. Retrieved from http://www.caba.org/resources/Documents/ IS-2008-93.pdf

Evans, D. (2011). The internet of things: How the next evolution of the internet is changing everything. CISCO White Paper, (April). Retrieved from http://scholar.google.com/ scholar?hl=en\&btnG=Search\&q=intitle:Th e+Internet+of +Things+How+the+Next+Ev olution+of+the+Internet + Is + Changing $+\mathrm{Ev}$ erything $\# 0$

Evans, D. (2012). How the Internet of Everything Will Change the World ... for the Better. Cisco blog. Retrieved April 01, 2014, from http://blogs.cisco.com/ioe/howthe-internet-of-everything-will-changethe-worldfor-the-better-infographic/

Evans, P. C., \& Annunziata, M. (2012). Industrial Internet: Pushing the Boundaries of Minds and Machines.
Gluhak, A., Krco, S., Nati, M., Pfisterer, D., Mitton, N., \& Razafindralambo, T. (2011). A survey on facilities for experimental internet of things research. IEEE Communications Magazine, 49(11), 58-67.

Gubbi, J., Buyya, R., Marusic, S., \& Palaniswami, M. (2013). Internet of Things (IoT): A vision, architectural elements, and future directions. Future Generation Computer Systems, 29(7), 1645-1660.

Guo, B., Zhang, D., \& Wang, Z. (2011). Living with Internet of Things: The Emergence of Embedded Intelligence. 2011 International Conference on Internet of Things and 4th International Conference on Cyber, Physical and Social Computing, 297-304.

Innocentive. (2012). Big Data and the Crowd (p. 14). Retrieved from http://www. bigdatarev.com/

Internet of Things European Research Cluster. (2012). The Internet of Things 2012: New Horizons. (I. G. Smith, O. Vermesan, P. Friess, \& A. Furness, Eds.) (3rd editio.). Halifax, UK. Retrieved from http://scholar. google.com/scholar?hl=en\&btnG=Search\& q=intitle:Internet+of+Things+2012:+New+ Horizons\#0

Khalique, M., Md Isa, A. H., \& Nassir bin Shaari, J. A. (2013). Predicting the Impact of Intellectual Capital Management on the Performance of SMEs in Electronics Industry in Kuching, Sarawak. IUP Journal of Knowledge Management, 11(4), 53-61. Retrieved from http://search.ebscohost. com/login.aspx?direct $=$ true $\& \mathrm{db}=$ bth $\& A N=$ 92605561\&site $=$ ehost-live

Krause, J., Ruxton, G. D., \& Krause, S. (2010). Swarm intelligence in animals and humans. Trends in Ecology \& Evolution, 25(1), 28-34. Libelium. (2014). Top 50 Internet of Things Applications. Retrieved March 25, 2014, from http://www.libelium.com/top_50_iot_ sensor_applications_ranking/

Luo, S., Xia, H., Yoshida, T., \& Wang, Z. (2009). Toward collective intelligence of online communities: A primitive conceptual model. Journal of Systems Science and ..., 18(70431001), 203-221. 
Mahidhar, V., \& Schatsky, D. (2013). The Internet of Things. Deloitte University Press. Retrieved March 25, 2014, from http://dupress.com/articles/the-internet-ofthings/

Malone, T. W., Laubacher, R., \& Dellarocas, C. (2010). The Collective Intelligence Genome. MIT Sloan Management Review, 51(3), 21-31.

Middleton, P., Kjeldsen, P., \& Tully, J. (2013). Forecast: The Internet of Things, Worldwide, 2013. Retrieved from https://www.gartner. com/doc/2625419/forecast-internet-thingsworldwide-

Nguyen, N. T. (2008). Inconsistency of Knowledge and Collective Intelligence. Cybernetics and Systems, 39, 542-562.

Presser, M., \& Krco, S. (2011). IOT - i D2 . 1: Initial report on IoT applications of strategic interest (p. 1-48).

Rose, A., McClean, C., \& Lisserman, M. (2012). Prepare Your Security Organization For The Internet Of Things. Retrieved from http:// www.forrester.com/Prepare+Your+Securit $\mathrm{y}+$ Organization+For+The+Internet+Of+Th ings/fulltext/-/E-RES85001

Salminen, J. (2012). Collective intelligence in humans: A literature review. arXiv Preprint arXiv:1204.3401. CI 2012. Retrieved from http://arxiv.org/abs/1204.3401
Tarkoma, S., \& Katasonov, A. (2011). Internet of Things Strategic Research Agenda (IoT-SRA). Internet of Things... (p. 40). Retrieved from http://books. google.com/books?hl=en \&lr=\&id=EugRvslW30C\&oi $=$ fnd \&pg $=$ PA $9 \& d q=$ Int ernet+of+Things+Strategic + Research + Agenda\&ots $=3 \mathrm{SA} 8 \mathrm{wCfzCu} \& \mathrm{sig}=\mathrm{hOm}-$ DZfBm6vXYjv16YEsrw4pMiw

Wise, S., Paton, R. a., \& Gegenhuber, T. (2012). Value co-creation through collective intelligence in the public sector: A review of US and European initiatives. Vine, 42(2), 251-276. doi:10.1108/03055721211227273

Woolley, A. W., Chabris, C. F., Pentland, A., Hashmi, N., \& Malone, T. (2010). Evidence for a Collective Intelligence Factor in the Performance of Human Groups. Science, $330,686-688$.

Xhafa, F., \& Bessis, N. (2014). Inter-cooperative Collective Intelligence: Techniques and Applications (p. 440). Springer. Retrieved from http://link.springer.com/content/ pdf/10.1007/978-3-642-35016-0.pdf 